simplified my own work in regard to marketing and recipes. In February when eggs were plentiful and cheap we were logically ready for egg lessons. As the work with cereals and potatoes had given an opportunity for the study of starchy foods, so eggs gave a similar opportunity of the study of proteins, not so completely as though the working basis had been the five principles, but completely enough to give the pupils a fairly comprehensive idea of the principles.

When we had completed the work on breakfasts each class prepared and served a complete breakfast. This brought in the work on setting the table and serving.

Before school closed in June we had begun on luncheons, but as I left the work at that time I was unable to try out my entire plan. But this much I can say, the general plan had worked far better than I had dared hope. It seemed to give a logical place to each principle and theory taught in a well-rounded course in cookery.

\title{
HOW I CONDUCT A PRACTICAL EXAMINATION IN FOOD PREPARATION.
}

\author{
By Katherine Livingston, \\ Lewis Institute, Chicago.
}

I find that a very helpful review for a class in cooking is a practical examination upon the recipes made in the class room. I conduct it by letting students draw slips containing incomplete recipes written in this way:

Prepare Baking Powder Biscuits using:

$\begin{array}{ccccc}\text { Flour } & \text { Fat } & \text { Salt } & \text { B. P. } & \text { Liquid } \\ ? & 1 \frac{1}{4} \text { tsp. } & \frac{1}{8} \text { tsp. } & \frac{1}{2} \text { tsp. } & 1 \frac{1}{2} \text { tsp. }\end{array}$

Write directions for combining ingredients and for baking:

Each girl draws a slip and answers the questions. After they are approved by the instructor she sets to work to make her product. If this takes only a short time she draws another slip and makes the second article. As each one is finished it is arranged upon a table, and at the end of the period criticised by the class. This exercise impresses definite proportions of ingredients of at least two dozen recipes upon the students and, because of the careful examination of each finished article by the class, promotes careful manipulation. 